\title{
PENERAPAN PENDEKATAN KONTEKSTUAL UNTUK MENINGKATKAN KETERAMPILAN MENULIS NARASI \\ PADA SISWA KELAS VII A SEMESTER I \\ SMP NEGERI 3 TAWANGSARI \\ TAHUN AJARAN 2013/2014
}

\author{
Nopvy Dwi Kusumawardani' ${ }^{1}$, Tutik Wahyuni² ${ }^{2}$, Sukarno ${ }^{3}$ \\ ${ }^{1,2,3}$ Program Studi Pendidikan Bahasa dan Sastra Indonesia \\ Fakultas Keguruan dan Ilmu Pendidikan \\ Universitas Veteran Bangun Nusantara Sukoharjo, Jawa Tengah Indonesia \\ Author correspondence: tutik21161@gmail.com
}

\begin{abstract}
ABSTRAK
Permasalahan penelitian ini adalah (1) Bagaimanakah penerapan pendekatan kontekstual untuk meningkatkan keterampilan menulis narasi siswa kelas VII A Semester I SMP Negeri 3 Tawangsari tahun ajaran 2013/2014? (2) Apakah penerapan pendekatan kontekstual dapat meningkatkan keterampilan menulis narasi pada siswa kelas VII A Semester I SMP Negeri 3 Tawangsari tahun ajaran 2013/2014? Tujuan penelitian ini adalah (1) Mendiskripsikan penerapan pendekatan kontekstual pada penulisan narasi siswa kelas VII A Semester I SMP Negeri 3 Tawangsari tahun ajaran 2013/2014 (2) Untuk meningkatkan keterampilan menulis narasi pada siswa kelas VII A Semester I SMP Negeri 3 Tawangsari tahun ajaran 2013/2014.

Penelitian ini berbentuk penelitian tindakan kelas. Objek penelitiannya adalah pembelajaran menulis narasi, sedangkan subjek penelitiannya adalah siswa kelas VII A SMP Negeri 3 Tawangsari sejumlah 23 siswa. Sumber data yang digunakan adalah dokumentasi, informan, dan tempat peristiwa. Teknik pengumpulan data yang digunakan adalah tes, observasi, dan wawancara. Teknik analisis data yang digunakan adalah teknik analisis deskriptif dan teknik analisis kritis. Penelitian ini dilaksanakan dalam dua siklus.

Hasil yang diperoleh dari penelitian ini (1) Penggunaan pendekatan kontekstual dilakukan dengan menggunakan tujuh komponen. Konstruktivisme, questioning, inquiry, learning community, modelling, refleksi, dan authentic assessment. Pada siklus I menggunakan media gambar bertema liburan. Pada siklus II menggunakan media gambar bertema berangkat sekolah (2) Penerapan pendekatan kontekstual dapat meningkatkan keterampilan menulis narasi siswa kelas VII A Semester I SMP Negeri 3 Tawangsari Tahun Ajaran 2013/2014. Hal ini ditandai dengan meningkatnya persentase keterampilan siswa menulis narasi yang telah mencapai ketuntasan $(\geq 70)$, yakni sebesar $65,22 \%$ pada siklus I naik $21,74 \%$ menjadi $86,96 \%$ pada siklus II.
\end{abstract}

Kata kunci: kemampuan menulis narasi, metode pendekatan kontekstual. 


\section{PENDAHULUAN}

Keterampilan menulis sangat penting dan berarti dalam peranannya. (Tarigan 1993: 1) menyatakan bahwa dari keempat keterampilan berbahasa yang ada, keterampilan menulis merupakan sebuah keterampilan berbahasa yang membutuhkan waktu paling lama. Proses orang belajar bahasa pun selalu dimulai dengan urutan menyimak, berbicara, membaca, dan menulis.

Sebagai bagian dari pembelajaran bahasa Indonesia, kegiatan menulis narasi pun sangatlah penting. Dengan memiliki kemampuan menulis narasi, siswa dapat lebih peka terhadap keadaan di sekitarnya, siswa dapat mengekpresikan pengalaman jiwa yang pernah dialami dengan menuangkannya dalam bentuk karangan narasi. Melalui kegiatan menulis narasi, siswa juga diajak untuk belajar merenungkan hakikat hidup meskipun masih dalam tataran yang sederhana. Oleh karena itu, siswa diharapkan dapat menguasai kemampuan menulis narasi. Berdasarkan hasil pengamatan dan wawancara dengan guru dan beberapa siswa dapat disimpulkan bahwa rendahnya kemampuan siswa dalam menulis narasi di atas disebabkan oleh beberapa faktor, yaitu: (1) siswa kesulitan dalam menuangkan idenya ke dalam bentuk tulisan yang utuh, (2) kurangnya keterampilan siswa dalam menentukan topik menulis narasi, (3) kurangnya keterampilan siswa dalam mengembangkan paragraf, (4) guru kesulitan dalam membangkitkan minat belajar siswa, (5) guru kesulitan menemukan metode atau cara yang tepat untuk menyampaikan materi menulis.

Untuk mengatasi masalah tersebut, peneliti bersama guru melakukan diskusi tukar pendapat untuk mencari solusi yang tepat dalam mengatasi kesulitan siswa dalam menuangkan idenya dalam bentuk tulisan narasi sehingga ketrampilan dan motivasi siswa untuk menulis narasi meningkat. Guru bersama peneliti menyadari bahwa kemampuan setiap anak tidak sama, melainkan memiliki tingkat pemahaman yang berbeda-beda. Untuk itu peneliti bersama guru memberikan alternatif penerapan pendekatan kontekstual untuk mengatasi permasalahan dalam pembelajaran menulis narasi tersebut. Menurut (Suprijono 2009: 79), pendekatan kontekstual atau Contextual Teaching and Learning (CTL) merupakan konsep yang membantu guru mengkaitkan antara materi yang diajarkannya dengan situasi dunia nyata dan mendorong peserta didik membuat hubungan antara pengetahuan yang dimilikinya dengan penerapannya dalam kehidupan mereka sebagai anggota keluarga dan masyarakat. Adapun komponen-komponen yang terdapat dalam CTL, yaitu (1) konstruktivisme, (2) inkuiri (Inquiry), (3) bertanya (questioning) (4) masyarakat belajar (learning community), (5) pemodelan (modeling), (6) refleksi, dan (7) penilaian outentik.

Berdasarkan diskusi antara peneliti dan guru bahasa indonesia metode pendekatan kontekstual digunakan sebagai salah satu sarana dalam memilih judul sebagai bahan untuk penelitian "Penerapan Pendekatan Kontekstual untuk Meningkatkan Keterampila Menulis Narasi pada Siswa Kelas VII A Semester I SMP Negeri 3 Tawangsari Tahun Ajaran 2013/2014". 


\section{Kemampuan menulis narasi}

Menurut Zain (Yusdi 2010: 10) mengartikan bahwa kemampuan adalah kesanggupan, kecakapan, kakuatan kita berusaha dengan diri sendiri. Sementara itu, Robbin (Yusdi 2010: 57) kemampuan berarti kapasitas seseorang individu untuk melakukan beragam tugas dalam suatu pekerjaan. Lebih lanjut Robbin menyatakan bahwa kemampuan (ability) adalah sebuah penilaian terkini atas apa yang dapat dilakukan seseorang.

Menulis merupakan salah satu dari empat aspek keterampilan berbahasa. Menulis merupakan bentuk komunikasi tidak langsung yang bermediakan tulisan. Menurut (Tarigan 1993: 22) menulis adalah menurunkan atau melukiskan lambang-lambang grafik yang menggambarkan suatu bahasa yang dipakai oleh seseorang, sehingga orang lain dapat membaca lambang-lambang grafik tersebut kalau mereka memahami bahasa dan gambaran grafik tersebut. Dari batasan di atas dapat diuraikan sejumlah unsur yang menyatu dalam kegiatan menulis. Unsur-unsur itu adalah (1) penulis; (2) makna atau ide yang disampaikan; (3) bahasa/ sistem tanda konvensional sebagai medium penyampai ide; (4) pembaca sasaran (target reader); (5) tujuan (sesuatu yang diinginkan penulis terhadap gagasan yang disampaikan kepada pembaca); dan (6) adanya interaksi antara penulis dan pembaca lewat tulisan tersebut.

(Keraf 2001: 136) merumuskan bahwa narasi adalah bentuk wacana yang berusaha menggambarkan dengan sejelas-jelasnya kepada pembaca suatu peristiwa yang telah terjadi. Jadi, peristiwa yang telah terjadi dan dikisahkan pada karangan narasi diceritakan selelngkap-lengkapnya sesuai dengan cerita sebenarnya. Peristiwa yang diceritakan tidak bersifat statis, melainkan bersifat dinamis dan terjadi dalam suatu rangkaian waktu.

Sedangkan menurut (Semi 1990: 32) narasi merupakan bentuk percakapan atau tulisan yang bertujuan menyampaikan atau menceritakan rangkaian peristiwa atau pengalaman manusia berdasarkan perkembangan dari waktu ke waktu. Atau dapat juga dirumuskan dengan cara lain: narasi adalah suatu bentuk wacana yang berusaha menggambarkan dengan sejelas-jelasnya kepada pembaca suatu peristiwa yang telah terjadi berdasarkan urutan waktu.

Narasi dapat dibedakan menjadi dua, yaitu 1) Narasi ekspositoris yaitu bertujuan untuk menggugah pikiran para pembaca untuk mengetahui apa yang dikisahkan. Sasaran utama hasil narasi ini adalah rasio, yaitu berupa perluasan pengetahuan para pembaca sesudah membaca kisah tersebut; 2) Narasi Sugestif yaitu sama juga dengan narasi ekspositoris, namun tujuan atau sasaran utamanya bukan mamperluas pengetahuan seseorang. Tujuan narasi sugestif adalah berusaha memberi makna atas peristiwa atau kejadian sebagai suatu pengalaman. Narasi ini selalu melibatkan daya khayal atau imajinasi pembacanya.

Ciri-ciri narasi menurut (Semi 1990: 33-34) yaitu 1) berupa cerita tentang peristiwa atau pengalaman manusia; 2) kejadian atau peristiwa yang disampaikan dapat berupa peristiwa atau kejadian yang benar-benar terjadi, dapat pula berupa semata-semata imajinasi, atau gabungan keduanya; 3) bedasarkan konflik. karena, tanpa konflik biasanya narasi tidak menarik; 4) memiliki nilai estetika karena isi dan cara penyampainya bersifat sastra, khususnya narasi berbentuk fiksi; 5) menekankan susunan kronologis (catatan: deskripsi menekankan susunan ruang); 6) biasanya memiliki dialog.

\section{Metode Pendekatan Kontekstual}

Pembelajaran kontekstual merupakan salah satu pendekatan pembelajaran yang melibatkan siswa secara penuh dalam proses pembelajaran. Belajar kontekstual bukan hanya mendengarkan dan mencatat, tetapi belajar adalah proses berpengalaman secara langsung. Melalui proses berpengalaman itu diharapkan perkembangan siswa terjadi 
secara utuh, yang tidak hanya berkembang dalam aspek kognitif saja, tetapi juga aspek afektif dan juga psikomotor.

Menurut (Suprijono 2009: 79), pendekatan kontekstual atau Contextual Teaching and Learning (CTL) merupakan konsep yang membantu guru mengaitkan antara materi yang diajarkannya dengan situasi dunia nyata dan mendorong peserta didik membuat hubungan antara pengetahuan yang dimilikinya dengan penerapannya dalam kehidupan mereka sebagai anggota keluarga dan masyarakat. Sementara itu (Trianto 2008: 20) menyatakan bahwa pendekatan kontekstual adalah suatu konsep belajar yang membantu guru mengaitkan antara materi yang diajarkannya dengan situasi dunia nyata siswa dan mendorong siswa membuat hubungan antara pengetahuan yang dimilikinya dengan penerapanya dalam kehidupan mereka sehari-hari, dengan melibatkan tujuh komponen utama pembelajaran kontekstual, yaitu: (1) konstruktivisme, (2) questioning, (3) inquiry, (4) learning community, (5) modelling, (6) refleksi, dan (7) authentic assessment.

Keunggulan pembelajaran kontekstual menurut (Sanjaya 2007: 272) antara lain sebagai berikut:

a. Dengan pembelajaran kontekstual dapat menekankan aktivitas berpikir siswa secara penuh, baik fisik maupun mental.

b. Pembelajaran kontekstual dapat menjadikan siswa belajar yang bukan mengahafal, tetapi proses berpengalaman dalam kehidupan nyata.

c. Kelas dalam pembelajaran kontekstual bukan sebagai tempat untuk memperoleh informasi, akan tetapi sebagai tempat untuk menguji data hasil temuan mereka di lapangan.

d. Materi pelajaran ditentukan oleh siswa sendiri, bukan hasil pemberian dari orang lain.

Disamping keunggulan seperti yang telah disebutkan diatas, pembelajaran kontekstual juga memiliki kelemahan. (Sanjaya 2007: 272) menengemukakan kelemahan kontekstual adalah "penerapan pembelajaran kontekstual merupakan pembelajaran yang kompleks dan sulit dilaksanakan dalam konteks pembelajaran. Kemudian pembelajaran dengan menggunakan pendekatan kontekstual juga membutuhkan waktu yang lama".

\section{Pendekatan Kontekstual dalam Pembelajaran Ketrampilan Menulis Narasi}

Secara garis besar langkah-langkah penerapan CTL dalam kelas sebagai berikut;

1) kembangkanlah pemikiran bahwa anak akan belajar lebih bemakna dengan cara bekerja sendiri, menemukan sendiri, dan mengkonstruksi sendiri pengetahuan dan ketrampilan barunya;

2) laksanakan sejauh mungkin kegiatan inkuiri untuk semua topik;

3) kembangkan sifat ingin tahu siswa dengan bertanya;

4) ciptakan masyarakat belajar (belajar dalam kelompok-kelompok);

5) hadirkan model sebagai contoh pembelajaran;

6) lakukan refleksi di akhir pertemuan;

7) lakukan penilaian yang sebenarnya dengan berbagai cara Depdiknas, (Trianto 2008: 25-26)

\section{Kerangka Berpikir}

Adapun kerangka berpikir dalam penelitian ini dapat digambarkan sebagai berikut:

\begin{tabular}{|c|} 
Kondisi Awal \\
\end{tabular} $\begin{gathered}\text { Pembelajaran berpusat pada } \\
\text { guru }\end{gathered}$




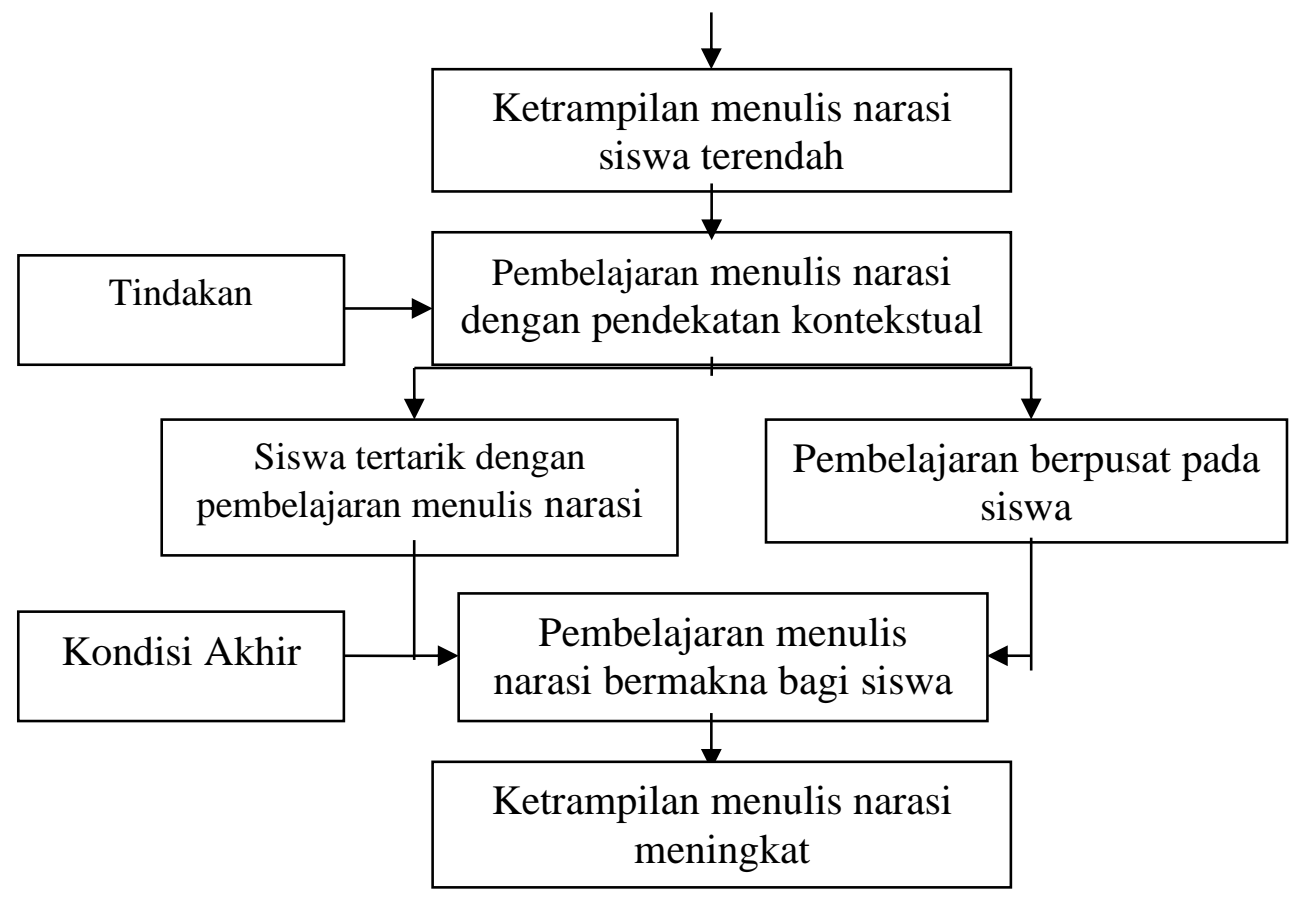

Gambar 1. Alur Kerangka Berpikir

\section{Tujuan Penelitian}

Tujuan penelitian yang ingin dicapai dalam penelitian ini adalah untuk:

1. Mendiskripsikan penerapan pendekatan kontekstual pada penulisan narasi siswa kelas VII A SMP Negeri 3 Tawangsari Tahun Ajaran 2013/2014

2. Meningkatkan keterampilan menulis narasi melalui pendekatan kontekstual pada siswa kelas VII A SMP Negeri 3 Tawangsari Tahun Ajaran 2013/2014.

\section{METODE PENELITIAN}

Jenis Penelitian

Penelitian ini merupakan penelitian tindakan kelas (PTK).

\section{Tempat dan Waktu Penelitian}

Penelitian ini dilaksanakan di SMP Negeri 3 Tawangsari yang terletak di desa Pundung Rejo, Tawangsari, Sukoharjo. Secara khusus, penelitian dilakukan di kelas VII A SMP Negeri 3 Tawangsari. Alasan pemilihan sekolah dan kelas VII A sebagai tempat penelitian adalah karena di sekolah ini ditemukan masalah yang berkaitan dengan tujuan penelitian yang akan dilakukan, dan kepraktisan waktu serta lokasi, karena sekolah ini menjadi tempat PPL, sehingga lebih mudah untuk mengumpulkan data.

Penelitian ini dilaksanakan mulai bulan September 2013 sampai bulan Desember 2013. Pelaksanaan penelitian disesuaikan dengan silabus dan disesuaikan dengan jadwal pembelajaran menulis narasi di kelas VII A SMP Negeri 3 Tawngsari, sehingga pelaksanaan penelitian bisa berjalan selaras dengan jadwal yang sudah ditentukan dan tidak menggangu kegiatan pembelajaran yang lain.

\section{Objek dan Subjek Penelitian}

Objek penelitian ini adalah keterampilan siswa menulis narasi di kelas VII A SMP Negeri 3 Tawngsari dan penerapan pendekatan kontekstual itu sendiri, sedangkan subjek penelitian adalah siswa kelas VII A SMP Negeri 3 Tawngsari yang berjumlah 23 orang. Siswa perempuan 
berjumlah 17 orang, sedangkan siswa laki-laki berjumlah 6 orang dan 1 guru mata pelajaran Bahasa Indonesia yang bernama Bapak Indarjo sebagai mitra kolaborasi.

\section{Rancangan Penelitian}

Penelitian ini dilakukan dengan cara mengadakan penelitian tindakan kelas dengan bertahap. Terdiri dari dua siklus masing-masing siklus terdiri empat tahap, perencanaan, tindakan, pengamatan, dan refleksi. Proses kegiatan tindakan kelas yang dilakukan adalah bertolak dari permasalahan yang akan dipecahkan, kemudian peneliti merencanakan suatu tindakan dan pelaksanaan. Proses penelitian ini dapat digambarkan dengan bagan yang disusun oleh Kurt Lewin (Suwandi 2006: 27-28).

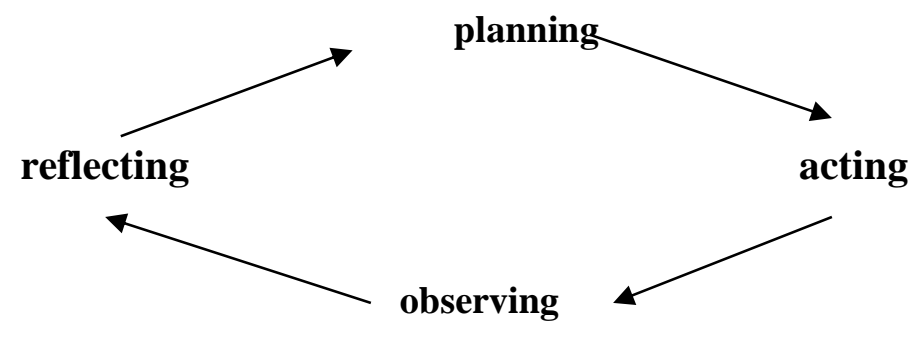

Gambar 2. Alur Penelitian Tindakan Kelas

\section{Sumber Data}

Sumber data dalam penelitian ini adalah:

1. Dokumen

Dokumen meliputi Rencana Pelaksanaan Pembelajaran, daftar nilai siswa pra dan pasca penelitian, catatan lapangan selama proses pembelajaran, dan hasil belajar siswa berupa tulisan narasi.

2. Informan

Informan yaitu seseorang yang dipandang mengetahui permasalahan yang ingin dikaji oleh peneliti dan bersedia memberikan informasi kepada peneliti. Dalam penelitian ini yang menjadi informan adalah guru bahasa Indonesia kelas VII dan siswa kelas VII A SMP Negeri 3 Tawngsari.

3. Tempat dan Peristiwa

Tempat dan peristiwa yang menjadi data dalam penelitian ini adalah objek atau tempat yang akan digunakan guru dan siswa untuk melaksanakan kegiatan pembelajaran menulis narasi yang akan berlangsung di lingkungan yang telah ditentukan.

\section{Teknik Pengumpulan Data}

\section{Teknik Tes}

Teknik tes yang digunakan dalam penelitian ini adalah tes menulis narasi. Tes menulis ini adalah tes yang diberikan kepada siswa saat pembelajaran menulis narasi melalui pendekatan kontekstual. Dalam penelitian ini tes menulis dilakukan sebanyak dua kali, yaitu pada siklus I dan siklus II. Tes yang digunakan untuk mengukur kemampuan menulis narasi siswa berupa karangan narasi yang dibuat siswa.

\section{Teknik Non Tes}

Teknik non tes yang digunakan untuk mengumpulkan data bersifat abstrak, yaitu berupa perubahan-perubahan sikap siswa setelah diadakan proses pembelajaran menulis menulis narasi dengan pendekatan kontekstual. Alat ukur yang digunakan dalam teknik ini meliputi: Observasi dan Wawancara. 


\section{Teknik Validitas Data}

Teknik validitas data yang digunakan dalam penelitian ini adalah triangulasi sumber dan triangulasi metode. Triangulasi sumber dengan menyesuaikan data-data yang diperoleh dari sumber atau informan yang berbeda, misalnya guru dan siswa. Triangulasi metode dipakai untuk menguji kevalidan data melalui metode penelitian yang berbeda. Dalam hal ini, peneliti menggunakan metode observasi dan wawancara.

\section{Teknik Analisis Data}

Teknik analisis data yang digunakan dalam penelitian ini adalah teknik analisis deskriptif dan teknik analisis kritis. Teknik analisis deskriptif menjelaskan hasil tindakan tiap siklus, sedangkan teknik analisis kritis digunakan untuk mengungkapkan kelebihan dan kekurangan kerja siswa dan guru dalam proses belajar-mengajar yang terjadi di dalam dan luar kelas selama penelitian berlangsung. Hasil analisis digunakan untuk menyusun rencana tindakan kelas berikutnya sesuai dengan siklus yang ada. Analisis dilakukan oleh guru dan peneliti secara bersama-sama.

\section{Indikator kinerja}

Indikator kinerja dalam penelitian diukur berdasarkan hasil evaluasi pembelajaran menulis karangan narasi yang diperoleh siswa di atas kriteria ketuntasan minimal (KKM) yaitu 70. Berdasarkan prosedur yang dilakukan selama pembelajaran menulis narasi pada siswa kelas VII A SMP Negeri 3 Tawangsari, indikator yang ingin dicapai dalam penelitian tindakan kelas ini adalah:

1. Meningkatnya keterampilan menulis narasi pada siswa kelas VII A SMP Negeri 3 Tawangsari dengan menggunakan metode pendekatan kontekstual.

2. Pada siklus I pembelajaran dikatakan berhasil apabila keterampilan menulis narasi siswa mencapai rata-rata kelas 70 dan siswa yang memperoleh $\geq 70$ mencapai $70 \%$.

3. Pada siklus II pembelajaran dikatakan berhasil apabila keterampilan menulis narasi siswa mencapai rata-rata kelas 70 dan siswa yang memperoleh $\geq 70$ mencapai $70 \%$.

\section{Peran dan Posisi Peneliti}

Peneliti adalah seorang mahasiswa semester VII yang sedang melakukan penelitian, pengamatan, dan observasi. Selain itu peneliti juga sebagai motivator bagi siswa yang sulit menemukan ide dalam proses pembelajaran menulis narasi, dan juga peneliti sebagai konseling bagi siswanya yang kurang memahami materi yang diberikan oleh guru. Peneliti juga berperan sebagai kontributor teori yang akan di terapkan dalam proses pembelajaran.

\section{Prosedur Penelitian}

Prosedur penelitian ini meliputi tahap-tahap sebagai berikut:

1. Rancangan siklus I

a. Tahap perencanaan tindakan, dilakukan dengan menyusun rencana penerapan pendekatan kontekstual di bawah bimbingan guru dalam pembelajaran menulis narasi yang mencakup kegiatan:

1) Guru bersama peneliti merancang skenario pembelajaran menulis puisi dengan pendekatan kontekstual untuk materi 'menulis karangan narasi' sesuai RPP yang disusun

2) Menyiapkan media pembelajaran berupa contoh karangan narasi

3) Menyusun lembar observasi sebagai pedoman pengamatan terhadap pelaksanaan pendekatan kontekstual

b. Tahap pelaksanaan tindakan, dilakukan pada bulan November 2013 dengan melaksanakan pembelajaran menulis narasi sesuai dengan skenario pembelajaran pada 
siswa, yakni mengoptimalkan penerapan pendekatan kontekstual yang ditempuh dengan langkah pembelajaran sebagai berikut:

1) Guru menjelaskan kompetensi dasar dan tujuan pembelajaran yang akan dicapai.

2) Guru menjelaskan manfaat dan tujuan kegiatan pembelajaran menulis.

3) Guru memberikan apersepsi dengan bertanya jawab kepada siswa tentang pengalamannya dalam mengarang. Apakah kesan dalam pengalamannya? Apakah bahagia, sedih, mengaharukan atau memalukan.

4) Guru meminta tanggapan siswa tentang pengetahuan karangan narasi, baik dari mendengarkan cerita orang lain maupun pengalaman pribadi siswa (kontruktivisme).

5) Guru menjelaskan materi yang berkaitan dengan mengarang narasi dan sekaligus memberikan contoh karangan narasi kepada siswa untuk didiskusikan menentukan tema dan ide pokok (inkuiri).

6) Guru membagi siswa menjadi 4 kelompok, kemudian memberikan kesempatan untuk menamai timnya (dibagi berdasarkan tema yang sama).

7) Siswa mendapat gambar peristiwa yang sama (permodelan).

8) Guru meminta siswa untuk menyusun kerangka karangan dalam bentuk draf, kemudian disusun dalam bentuk karangan narasi.

9) Siswa mendiskusikan hasil pekerjaannya dengan teman satu kelompok dengan cara memeriksa, mengoreksi dan memperbaiki kesalahan dalam karangan narasi (masyarakat belajar).

10) Guru bersama siswa mengevaluasi dan menyimpulkan hasil pembelajaran yang telah berlangsung.

c. Tahap observasi dan interpretasi, dilakukan pada saat pembelajaran berlangsung. Tahap ini dilakukan oleh guru maupun peneliti dengan mengamati dan menginterpretasikan aktivitas penerapan pendekatan kontekstual dalam pembelajaran menulis narasi baik pada proses maupun hasil, dengan menggunakan lembar observasi untuk mendapatkan data tentang kekurangan dan kemajuan aplikasi tindakan pada siklus pertama. Selain itu, untuk memperoleh data yang akurat, juga dilakukan wawancara dengan para siswa dan Bapak Indarjo selaku guru Bahasa Indonesia. Hal ini untuk mengetahui motivasi yang diperoleh siswa setelah tindakan.

d. Tahap analisis dan refleksi, dilakukan oleh peneliti dan guru dengan cara menganalisis tulisan narasi siswa, hasil observasi, dan wawancara. Berdasarkan hasil analisis tersebut akan diperoleh kesimpulan bagian mana yang perlu diperbaiki atau disempurnakan dan mana yang telah memenuhi target. Hasil refleksi digunakan sebagai masukan untuk perbaikan siklus II.

2. Rancangan siklus II

Pada siklus kedua dilakukan tahapan-tahapan seperti pada siklus pertama, tetapi didahului dengan perencanaan ulang berdasarkan hasil-hasil yang diperoleh pada siklus pertama (refleksi), sehingga kelemahan-kelemahan yang terjadi pada siklus pertama tidak terjadi pada siklus kedua. Tindakan pada siklus kedua tetap menggunakan pendekatan kontekstual dalam pembelajaran menulis narasi.

\section{HASIL DAN PEMBAHASAN}

\section{Deskripsi Kondisi Awal}

Kondisi awal keterampilan siswa dalam menulis narasi diketahui dengan terlebih dahulu peneliti mengadakan survei awal pada hari kamis 3 Oktober 2013., di ruang kelas VII A SMP Negeri 3 Tawangsari. Peneliti memfokuskan untuk mengamati permasalahan mendasar yang dihadapi siswa dan guru pada pembelajaran menulis, khususnya narasi.

Berdasarkan observasi tersebut, proses pembelajaran menulis narasi pada kelas VII A SMP Negeri 3 Tawangsari yang masih mengalami kesulitan menuangkan idenya ke dalam bentuk tulisan dengan menggunakan bahasa Indonesia yang baik dan benar, dan pemilihan kata atau 
kosakata yang kurang tepat. Menurut hasil pengamatan peneliti, rendahnya keterampilan menulis narasi di kelas VII A SMP Negeri 3 Tawangsari tersebut disebabkan oleh beberapa faktor, yaitu: (1) siswa kesulitan dalam menuangkan idenya ke dalam bentuk tulisan yang utuh, (2) kurangnya keterampilan siswa dalam menentukan topik menulis narasi, (3) kurangnya keterampilan siswa dalam mengembangkan paragraf, (4) guru kesulitan dalam membangkitkan minat belajar siswa, (5) guru kesulitan menemukan metode atau cara yang tepat untuk menyampaikan materi menulis.

Berdasarkan hasil pengamatan terhadap proses belajar mengajar diperoleh data sebagai berikut: terdapat 11 siswa $(47,9 \%)$ nilai masih kurang dari 70 . Sedangkan 12 siswa atau $(52,1 \%)$ masuk dalam katagori cukup. Nilai rata-rata keterampilan menulis narasi siswa sebelum tindakan sebesar 67,39 atau dengan kategori kurang.

\section{Hasil penelitian Siklus I}

Tindakan siklus I dilaksanakan pada hari Sabtu, 30 November 2013, di dalam ruang kelas VII A. Pembelajaran menulis narasi pada siklus I ini berlangsung dalam satu pertemuan selama 80 menit $(2 \times 40$ menit $=2$ jam pelajaran $)$ mulai pukul $07.40-09.00 \mathrm{WIB}$.

Tahap awal Guru memasuki kelas, lalu mengabsensi siswa. Kemudian guru menjelaskan kompetensi dasar dan tujuan pembelajaran yang akan dicapai. Pelajaran diawali dengan pemberian apersepsi berupa tanya jawab tentang pengalaman siswa dalam mengarang Apakah kesan dalam pengalamannya? Apakah bahagia, sedih, mengaharukan atau memalukan.

Guru kemudian meminta tanggapan siswa tentang pengetahuan karangan narasi, baik dari mendengarkan cerita orang lain maupun pengalaman pribadi siswa. Setelah itu guru menjelaskan materi yang berkaitan dengan mengarang narasi dan sekaligus memberikan contoh karangan narasi yang bertemakan liburan kepada siswa untuk didiskusikan menentukan tema dan ide pokok.

Guru membagi siswa menjadi 4 kelompok, kemudian memberikan kesempatan untuk menamai timnya (dibagi berdasarkan tema yang sama) dan setiap kelompok diberi gambar peristiwa yang bertema liburan. Setelah itu guru meminta siswa untuk menyusun kerangka karangan dalam bentuk draf, kemudian disusun dalam bentuk karangan narasi. Apabila sudah selesai siswa dapat mendiskusikan hasil pekerjaannya dengan teman satu kelompok dengan cara memeriksa, mengoreksi dan memperbaiki kesalahan dalam karangan narasi.

Berdasarkan hasil pengamatan terhadap proses belajar mengajar dalam menulis narasi pada kelas VII A SMP Negeri 3 Tawangsari belum ada siswa yang dapat mencapai kategori sangat baik dengan skor 91-100. Kategori baik dengan skor 81-90 dicapai dua siswa (8,7\%). Kategori cukup dengan skor 70-80 dicapai oleh 13 siswa (56,52\%), sedangkan kategori kurang dengan skor di bawah 70 masih terdapat sebanyak $8(34,78 \%)$ siswa atau belum memenuhi KKM 70. Jadi, nilai rata-rata keterampilan menulis narasi siswa pada siklus I sebesar 70,69. Dari hasil keterampilan menulis narasi, siswa yang tuntas 15 siswa $(65,22 \%)$ dan yang belum tuntas 8 siswa $(34,78 \%)$.

\section{Hasil penelitian Siklus II}

Tindakan pada siklus II dilaksanakan dalam satu pertemuan, yaitu pada hari Kamis, 5 Desember 2013 di ruang kelas VII A SMP Negeri 3 Tawangsari. Siklus II dilakukan mulai perencanaan sampai refleksi. Aktivitas pembelajaran pada siklus II dilakukan dengan menggunakan metode pendekatan kontekstual untuk mendapatkan suasana belajar yang lebih menyenangkan, mempermudah siswa menuangkan ide, menentukan topik dan mengembangkan paragraf.

Tahap awal guru membuka pelajaran dengan mengucap salam dan mengabsensi siswa. Kemudian melakukan apersepsi dengan menanyakan kesulitan yang dihadapi siswa saat pembelajaran menulis narasi pada siklus I. Memberikan rewards berupa tepuk tangan, nilai tambahan, dan hadiah kepada siswa yang memperoleh nilai karangan narasi terbaik pada siklus I, yaitu Cyntya Fara Dilla dengan karangannya berjudul Libur ke Waduk Gajah Mungkur dan Lina Dwi Arini dengan karangannya yang berjudul Liburan ke rumah saudara. 
Kemudian guru membagi siswa menjadi 4 kelompok, dan memberi kesampatan untuk menamai timnya. Setiap kelompok mendapatkan gambar yang bertema berangkat sekolah untuk membantu siswa berimajinasi menuangkan idenya ke dalam karangan narasi. Setelah selesai mengerjakan karangan narasi siswa berdiskusi saling mengoreksi pekerjaan satu kelompok. Kemudian guru dan siswa melakukan refleksi.

Berdasarkan hasil pengamatan terhadap proses belajar mengajar dalam menulis narasi untuk kategori baik dengan skor 81-90 ada sepuluh siswa (43,48\%). Kategori cukup dengan skor 70-80 telah dicapai oleh sepuluh siswa (43,48\%). Sedangkan yang memperoleh nilai dibawah 70 ada tiga siswa $(13,04 \%)$. Secara keseluruhan rata-rata kelas dari 23 siswa adalah 77 . keterampilan menulis narasi siswa kelas VII A SMP Negeri 3 Tawangsari mengalami peningkatan dan sudah banyak memenuhi target pencapain nilai 70, 20 siswa $(86,96 \%)$ sudah mencapai nilai KKM, dan tiga siswa $(13,04 \%)$ nilai masih di bawah KKM.

\section{Pembahasan}

Penelitian Tindakan Kelas dilaksanakan peneliti dalam dua siklus. Berdasarkan tindakantindakan yang telah dilakukan, dapat dikatakan bahwa penerapan pendekatan kontekstual dalam pembelajaran menulis narasi di kelas VII A SMP Negeri 3 Tawangsari telah berhasil. Keberhasilan metode pendekatan kontekstual dalam upaya meningkatkan keterampilan menulis narasi dapat dilihat tercapainya pada indikator keberhasilan yang sudah ditentukaan. Adapun tercapainya indikator keberhasilan pada siklus I dan II sebagai berikut:

1. Keterampilan menulis narasi pada siswa kelas VII A SMP Negeri 3 Tawangsari dengan menggunakan metode pendekatan kontekstual mengalami peningkatan dari prasiklus ke siklus I sebesar 13,05\% dan dari siklus I ke siklus II sebesar 21,74\%.

2. Pada siklus I yang memperoleh nilai $\geq 70$ ada 15 siswa $(65,22 \%)$ dengan nilai rata-rata kelas 70,69.

3. Pada siklus II yang memperoleh nilai $\geq 70$ meningkat menjadi 20 siswa $(86,96 \%)$ dengan nilai rata-rata kelas 77 .

Jadi nilai kondisi (prasiklus sampai siklus I dan siklus II) terjadi peningkatan siswa yang memenuhi KKM dari 12 siswa menjadi 20 siswa (atau 8 siswa/ 34,8\%).

\section{SIMPULAN, IMPLIKASI DAN SARAN Simpulan} bahwa:

Berdasarkan deskripsi pada hasil penelitian tindakan kelas di atas, dapat disimpulkan

1. Penggunaan metode pendekatan kontekstual dilakukan dengan cara melibatkan tujuh komponen utama pembelajaran kontekstual, yaitu: (1) konstruktivisme, (2) questioning, (3) inquiry, (4) learning community, (5) modelling, (6) refleksi, dan (7) authentic assessment. Membangun keaktifan siswa, guru meminta tanggapan siswa tentang pengetahuan karangan narasi baik dari mendengarkan cerita orang lain maupun pengalaman pribadi. Apabila tidak mengerti tentang karangan narasi, siswa dapat langsung bertanya kepada guru atau teman. Kemudian siswa diminta untuk menemukan tema atau ide pokok untuk menulis narasi. Siswa dapat berdiskusi dengan teman kelompoknya jika menemukan kesulitan dalam mengerjakan tugas menulis narasi. Guru juga memberi media gambar seri untuk membantu siswa berimajinasi dalam menulis narasi. Kegiatan akhir dalam 
pembalajaran guru dan siswa melakukan refleksi/simpulan pembelajaran dan guru memberi penilaian

2. Penerapan metode pendekatan kontekstual terbukti dapat meningkatkan keterampilan menulis narasi siswa kelas VIIA SMP Negeri 3 Tawangsari Tahun Ajaran 2013/2014. Hal ini terbukti dari hasil tes menulis narasi siswa mengalami peningkatan dari prasiklus ke siklus I sebesar 13,05\% dan dari siklus I ke siklus II sebesar $21,74 \%$. Pada prasiklus yang memperoleh nilai $\geq 70$ ada 12 siswa $(52,17 \%)$ dengan nilai rata-rata 67,39. Pada siklus I yang memperoleh nilai $\geq 70$ ada 15 siswa $(65,22 \%)$ dengan nilai rata-rata kelas 70,69. Pada siklus II meningkat menjadi 20 siswa $(86,96 \%)$ yang memperoleh nilai $\geq 70$ dengan nilai rata-rata kelas 77.

\section{Implikasi}

Simpulan hasil penelitian yang telah diuraikan di atas mempunyai implikasi penting terhadap upaya meningkatkan keterampilan menulis narasi. Penerapan pendekatan kontekstual untuk meningkatkan keterampilan menulis narasi pada siswa kelas VII A Semester I SMP Negeri 3 Tawangsari yang dilaksanakan dalam dua siklus ini menunjukkan adanya peningkatan dalam setiap siklusnya. Secara keseluruhan yang tadinya siswa belum terampil menulis narasi dengan baik, setelah mengalami pembelajaran menggunakan pendekatan kontekstual, maka keterampilan menulis narasi kelas VIIA meningkat.

Pelaksanaan dari tujuh komponen dalam pendekatan kontekstual memberi pengaruh positif dalam pembelajaran menulis narasi. Dengan komponen bertanya (questioning) dapat membangkitkan motivasi siswa, dapat menggali informasi, pemahaman dan mefokuskan perhatian. Dengan komponen konstruktivisme dan inquiry, dapat membangun keaktifan siswa dan pengetahuan sedikit demi sedikit dari mengungkap isi, pengorganisasian, penggunaan kosakata, pengembangan bahasa, maupun mekanik. Dengan menggunakan masyarakat belajar (learning community), dalam diri anak akan tertanam rasa kebersamaan, kerjasama dan membina interaksi siwa. Dengan komponen permodelan, siswa dapat termotivasi dalam mengikuti pembelajaran. Dengan demikian, pendekatan kontekstual dalam pembelajaran menulis, khususnya menulis narasi perlu dikembangkan penggunaannya dalam pembelajaran Bahasa Indonesia di Sekolah Menengah Pertama maupun sekolah untuk jenjang di atasnya.

Penerapan pendekatan kontekstual dalam penelitian ini, dapat memperkaya ilmu pengetahuan tentang penelitian tindakan kelas, sehingga dapat memotivasi guru dan peneliti lain untuk melakukan penelitian sejenis dengan tujuan meningkatkan kualitas pembelajaran. Penelitian ini juga dapat dijadikan referensi untuk mengembangkan pembelajaran yang lebih kreatif dan inovatif, sehingga dapat digunakan sebagai bahan pertimbangan untuk menerapkan pendekatan kontekstual sebagai pendekatan dalam pembelajaran. 


\section{Saran}

Berkaitan dengan hasil yang dicapai penelitian tindakan kelas ini, peneliti mengajukan saransaran sebagai berikut ini.

1. Bagi siswa

Siswa hendaknya berperan secara aktif dalam mengikuti proses pembelajaran menulis narasi dengan menggunakan metode pendekatan kontekstual, sehingga proses pembelajaran dapat berjalan dengan baik dan hasil yang diharapkan dapat tercapai secara optimal. Di samping itu siswa perlu memberikan masukan ataupun saran apabila siswa kurang setuju terhadap cara mengajar guru yang bersangkutan, sehingga pembelajaran dengan pendekatan kontekstual dapat berlangsung secara efektif dan efisien.

\section{Bagi guru}

Guru hendaknya mempertimbangkan penerapan pendekatan kontekstual dalam pembelajaran menulis narasi, karena pendekatan kontekstual merupakan pendekatan yang menciptakan suasana pembelajaran yang aktif dan menyenangkan bagi siswa. Selain itu, dengan diterapkannya pendekatan kontekstual siswa menjadi lebih mudah menuliskan apa yang mereka pikirkan karena berkaitan dengan kehidupan nyata.

\section{Bagi sekolah}

Untuk meningkatkan kualitas pembelajaran, khususnya pembelajaran menulis narasi kompetensi guru perlu ditingkatkan. Kompetensi tersebut berpengaruh terhadap kinerja guru dalam pembelajaran di kelas. Untuk itu, kepala sekolah disarankan untuk memotivasi guru meningkatkan kompetensinya dan memperluas wawasan mengenai pendekatan-pendekatan yang kreatif dan inovatif dalam pembelajaran.

\section{DAFTAR PUSTAKA}

Keraf, Gorys. 2001. Argumentasi Dan Narasi. Jakarta: Gramedia Pustaka Utama.

Sanjaya, Wina. 2007. Strategi Pembelajaran Berorientasi Standar Proses Pendidikan. Bandung: Kencana.

Sari, Novita Mustika. 2012. "Peningkatan Prestasi Belajar Membaca Melalui Pendekatan Kontekstual Siswa Kelas I SD Negeri Banmati Kabupaten Sukoharjo.” Skripsi.

Semi, Atar. 1990. Menulis Efektif. Padang: Angkasa Raya.

Suprijono, Agus. 2009. Cooperative Learning. Yogyakarta: Pustaka Pelajar.

Suwandi, Sarwiji. 2006. Penelitian Tindakan Kelas (PTK) Dan Penulisan Karya Ilmiah. Surakarta: Panitia Sertifikasi Guru Rayon 13 FKIP UNS Surakarta.

Tarigan, Henry Guntur. 1993. Menulis Sebagai Suatu Keterampilan Berbahasa. Bandung: Angkasa. 
Trianto. 2008. Mendesain Pembelajaran Kontekstual. Jakarta: Cerdas Pustaka Publiser.

Yusdi, Milman. 2010. "Pengertian Kemampuan." (31 Agustus 2013). http://milmanyusdi.blogspot.com. 